\title{
Policy Instrument of Integrated Self-Sufficient City on Transmigration Area in Northern Bengkulu, the Province of Bengkulu
}

\author{
Iqbal M. Mujtahid ${ }^{1}$, Sri Suwitri², Titi Darm $^{3}$ \\ 1,2,3 Universitas Terbuka UPBJJ Bengkulu, Jl. Sadang Lingkar Barat, Bengkulu, Indonesia
}

\begin{abstract}
The purpose of this study is to describe and analyze Integrated Self-Sufficient City development policy instrument. This research was conducted with qualitative methods, data presentation is done through interviews, documentation and observation, while data analysis is performed by adopting the thought Miles, Huberman and Saldana (2014) by using interactive methods of analysis models. The results of this study concluded that "policy instruments Integrated Self-Sufficient City construction on transmigration area in Northern Bengkulu district proven cannot be implemented to the fullest". Conclusion of the existing findings as described from the evidence that there are the following. Recommendations are: The success of Integrated Self-Sufficient City policy implementation can be perceived by the public and appropriate goal would initially need to do various strengthening and improvement of the implementation of the policy. So that the reinforcement can be realized if the strengthening of institutional functions in every sector can formulate policies are clear and measurable. To the researchers have several recommendations that may be referenced regarding synergize the various types of policy instruments by taking into account local conditions and regulations as well as regional development.Integrated Self-Sufficient City promoting policies to all working Units local goverment that Integrated Self-Sufficient City program development across sectors that require coordination both at central and regional level.
\end{abstract}

Keywords: Transmigration; Integrated Self-Sufficient City Development; Policy Instrument

\section{Introduction}

The background of urban affairs in developing countries is the result of the large number of population so that the need for settlements, housing and land used for cultivating which generally become the livelihood of urban communities coming from rural or so-called transmigrants are not balanced due to the high demand and limited land. Public land use planning strategies are traditionally based on intermittent incremental decision making. Rule based on carrying capacity provides an alternative method for evaluating land use. capacity issues are the focal point of land use in planning strategies. Inhibiting factors are institutional arrangements that cannot afford to consider the environment systemically, the limited ability of science, decision makers and communities to identify the needs and capacity levels [1].
Transmigration in Indonesia has passed long stages with various achievements and failures. In the future, the transmigration program continues, because the territory of the Unitary State of the Republic of Indonesia (NKRI) has geographically thousands of islands, with large populations whose distribution has not been balanced with the carrying capacity of nature and the environment. The purpose of transmigration is in line with Law No. 29/2009 [2] on the Amendment of Law Number 15 Year 1997 concerning Government Transmigration and Government Regulation No. 3 of 2014 concerning the Implementation of Transmigration which states that the purpose of transmigration development is to improve the welfare of transmigrants and the surrounding community, increasing and equitable regional development, and strengthening the unity of the nation. 
Since 2007, 48 KTMs have been rolled out throughout Indonesia and have lasted four generations.
The four generations of KTM development can be seen as in the following table:

Table 1. KTM Development Generation In Indonesia

\begin{tabular}{|c|c|c|}
\hline $\begin{array}{c}\text { Numb } \\
\text { er }\end{array}$ & Name of KTM & Province \\
\hline 1 & 2 & 3 \\
\hline \multirow[t]{4}{*}{ I } & Mesuji KabupatenTulangBawang & Provinsi Lampung \\
\hline & Telang Kabupaten Banyuasin, & Provinsi Sumatera Selatan \\
\hline & Rambutan Parir Kabupaten OganIlir, & Provinsi Sumatera Selatan \\
\hline & Belitang Kabupaten OKU Timur & Provinsi Sumatera Selatan \\
\hline \multirow[t]{4}{*}{ II } & Geregai Kabupaten Tanjung Jabung & Provinsi Jambi \\
\hline & Lunan Silaut Kabupaten Pesisir Selatan & Provinsi Sumatera Barat \\
\hline & Tobadak Kabupaten Mamuju & Provinsi Sulawesi Barat \\
\hline & Rasau Jaya Kabupaten Kubu Raya & Provinsi Kalimantan Barat \\
\hline \multirow[t]{2}{*}{ III } & Labangka Kabupaten Sumbawa & Provinsi Nusa Tenggara Barat \\
\hline & Hialu Kabupaten Konawe Utara & Provinsi Sulawesi Tenggara \\
\hline \multirow[t]{12}{*}{ IV } & Mahalona, KabupatenLuwuTimur, & Provinsi Sulawesi Selatan \\
\hline & Air Terang Kabupaten Buol & Provinsi Sulawesi Tengah \\
\hline & Maloy Kaliorang Kabupaten Kutai Timur & Provinsi Kalimantan Timur \\
\hline & Lagita (Lais,GiriKencana, Ketahun) & Provinsi Bengkulu \\
\hline & Pau Mandiangin Kabupaten Sarolangun & Provinsi Jambi \\
\hline & Subah Kabupaten Sambas & Provinsi Kalimantan Barat \\
\hline & Cahaya Baru Kabupaten Batola & Provinsi Kalimantan Selatan \\
\hline & Sarudu Baras Mamuju Utara & Provinsi Sulawesi Barat \\
\hline & Pawonsari Kabupaten Boalemo & ProvinsiGorontalo \\
\hline & Dataran Bulan Tojo Una Una & Provinsi Sulawesi Tengah \\
\hline & Bungku Kabupaten Morowali, & Provinsi Sulawesi Tengah \\
\hline & Salor Kabupaten Merauke & Provinsi Papua \\
\hline
\end{tabular}

Source: Pusdatin Balitfo Ministry of Nakertrans RI, 2013

\section{Methodology}

This research was conducted with qualitative methods, data presentation is done through interviews, documentation and observation, while data analysis is performed by adopting the thought Miles, Huberman and Saldana (2014) by using interactive methods of analysis models. The results of this study concluded that "policy instruments Integrated Self-Sufficient City construction on transmigration area in Northern Bengkulu district proven cannot be implemented to the fullest".

\section{Discussion}

According to Howlett \& Ramesh [3] policy objectives and means of varying degrees of abstraction and policy application, how to design policies as an attempt to match goals and instruments well within the entire category. That is, successful policy design requires:

1. Policy goals, objectives, and targets become coherent.

2. Implementation preference, on the policy tool and calibration tool should bealso consistent

3. Policy objectives and implementation of preferences: policy objectives and policy tools and policy objectives and calibration tools, should also be congruent and convergent. Choice of policy instruments so that it can be seen the results of a larger framework of government established from the mode and logic of the policy regime.

Local Government of North Bengkulu Regency proposes development of Lagita KTM because this area has prospect and potential of development of settlement, agriculture and plantation. As KTM is built through development and expansion mechanism based on Decree of Minister of Transmigration Number 214 / MEN / V / 2007 concerning General Guidelines of Development and Expansion of Integrated City in Transmigration Area.

The development and expansion of KTM Lagita begins with the submission of KTM candidate proposal with 1: 50.000 scale area map by North Bengkulu Regency Government to Minister through Governor. In the next stage, Bengkulu Provincial Government conducts studies and coordinates among departments. The submitted proposals meet the criteria established then the Governor publishes recommendations submitted to the Minister. At the ministry level the recommendations are reviewed and coordinated among ministries. Furthermore, the minister shall issue approval letter of KTM candidate 
location with the consideration that the proposal has fulfilled the criteria specified.

The criteria and requirements of KTM area in accordance with the Decree of the Minister of Manpower and Transmigration R.I Number 214 Year 2007 [4] About Guidelines for Development and Development of Integrated Integrated City (KTM) in Transmigration Area are as follows:

1. Enter in the cultivation area (APL and HPK).

2. Not in conflict with RTRWP / RTRWN.

3. KTM extent of at least 18,000 ha and capacity of \pm 9,000 households consists of transmigrants and residents.

4. Have the excellent potential that meets economies of scale.

5. Have easy relationship with existing growth center.

6. The proposed area is free from allotment of other land, does not contain social problems, is the aspiration of the community and or business entity.

7. The proposed KTM is a collective agreement between the district government and the DPRD.

8. Available land for KTM center $\pm 120 \mathrm{Ha}$, development of TSM minimum $500 \mathrm{Ha}$ and development of new settlement minimum 1000 Ha.

In the early stages of planning after the area is approved by the Ministry of Manpower and Transmigration, the Government of North Bengkulu Regency prepares a KTM master plan that contains spatial development plans, economic enterprises, community development described in medium and annual development plans. Furthermore, the masterplan KTM is declared as Decree (SK) of Bengkulu Utara Regent Number 233 of 2009 [5], then socialized to all stakeholders involved in development and development of KTM. In 2011 the Regional Regulation (PERDA) No. 6 of 2011 on Regional Medium Term Development Plan (RPJMND) of North Bengkulu Regency 2011-2016 was approved. In the framework of controlling the implementation of the development and expansion of KTM in the form of Working Groups (Pokja) at the central, provincial and district levels. As the coordinator of the central working group is the Coordinating Minister for Economic Affairs. The Coordinator of the Provincial working group is the Governor and the Regent as the coordinator of the district working group. (Figure 1.)

In the initial stages of planning after the area is approved by the Minister of Nakertrans, the Government of North Bengkulu Regency prepares a KTM master plan that contains spatial development plans, economic enterprises, community development described in medium and annual development plans.

As a transmigration area of development and expansion activities, a holistic and comprehensive program of KTM activities is designed, covering the development of all areas involving inter-agency and multisector. Therefore, the formulation of work program is needed so that later can produce maximum results.

\section{Conclusion}

The process of formulating the program instruments includes part of the development planning and development of the KTM areas listed in the government work plan policies for the coming year. Each formulation of the instrument of course activities is always based on the basis of the problems or strategic issues contained in the area. Lagita KTM program in this northern Bengkulu district, ideally to be able to solve the existing problems in the transmigration area whether it is economic problems or other issues that become integrated in a work program. The formulation of activity program that will be done at KTM Lagita involves various parties and elements of society either from the Local Government and also the community.

The formulation of policy direction and work program in the framework of development and expansion of KTM Lagita is conducted together in a coordination meeting between SKPD in the framework of preparation of RPMJD Kabupaten Bengkulu Utara. The direction of the work program is a description of what will be done and achieved by the government of North Bengkulu Regency in order to increase the development of KTM.

In the future research, the policy instrument related to sustainable environment as part of transmigration needs to be highlighted due to impacts of transmigration tends to increase enviromental damages.

\section{References and Notes}

1. K. M. Livingston, "A critical evaluation of the utility and implementation of carrying capacity based land-use planning regulations, with a case study of cape cod, massachusetts (Order No. 1376747. Available from ProQuest Dissertations \& Theses Full Text: The Humanities and Social Sciences Collection. (304221336)". Retrieved from

http://search.proquest.com/docview/304221336?a c countid $=25704$

2. Republic of Indonesia, "Law Number 29 of 2009 on Transmigration", Jakarta: State Secretariat, (2009). 
3. M. Howleet, \& M. Ramesh, "Studying Public Policy: Policy Cycles and Policy Subsystems. Oxford University Press", USA, (1995).

4. Decree of the Minister of Manpower and Transmigration, "Regulation of the Minister of Manpower and Transmigration No. 214 of 2007 concerning General Guidelines for the Development and Development of Independent Integrated City in the Transmigration Area", Jakarta: Cabinet Secretariat, (2007).

5. Decision of North Bengkulu Regent, "Decision of Bupati Number 233 Year 2009 About the
Stipulation / Appointment of Land Procurement For Location of Integrated Central City Development Center (KTM) Lagita, North Bengkulu Regenc", North Bengkulu: Regional Secretariat, (2009).

6. Decree of the Minister of Manpower and Transmigration, "Decree of Minister of Manpower and Transmigration Number 137 Year 2008 About Determination of Location of Development and Development of Integrated Integrated City (KTM) in Transmigration Area, Jakarta: Cabinet Secretariat, (2008). 